\title{
The Impact Of Implementation Based on The Policy Development Neighborhood for The Social Welfare in The City Of Manado
}

\author{
$1^{\text {st }}$ Jeane E. Langkai \\ Public Administration Department \\ Faculty of Social Science \\ Universitas Negeri Manado, \\ Manado, Indonesia \\ jeanelangkai@unima.ac.id \\ $4^{\text {th }}$ Itje Pangkey \\ Public Administration Department \\ Faculty of Social Science \\ Universitas Negeri Manado \\ Manado, Indonesia \\ Itjepangkey@unima.ac.id
}

\author{
$2^{\text {nd }}$ Haedar Akib \\ Public Administration Department \\ Universitas Negeri Makasar \\ Makassar, Indonesia \\ $5^{\text {th }}$ Willem R. Mawitjere \\ Law Department \\ Faculty of Social Science \\ Universitas Negeri Manado \\ Manado, Indonesia \\ willemmawitjere@unima.ac.id
}

\author{
$3^{\text {rd }}$ Jetty Erna Hilda Mokat \\ Publik Administration Department \\ Faculty of Social Science \\ Universitas Negeri Manado \\ Manado, Indonesia \\ Jettymokat@yahoo.co.id \\ $6^{\text {th }}$ Recky H E Sendouw \\ Public Administration Department \\ Faculty of Social Science \\ Universitas Negeri Manado \\ Manado, Indonesia \\ reckysendouw@unima.ac.id
}

\begin{abstract}
Countermeasure of destitute society's welfare in Manado conducted by implementing Neighborhood Based Establishment (PBL), with the program of increasing weak economic society's revenue. Policy implementer is Society Empowerment Board and Domain Government (BPMPK) and 504 heads of domain. Main focus question in this research is why the implementation of PBL had not affected yet onto the increasing of destitute society's welfare in Manado, and focusing at the independent aspect of policy implementation. The description of research focus is, what is meant by independent aspect are the technical independent complex components such as: (1) Territorial vast, amount and density of population, (2) diversity of target's behavior, (3) percentage of target groups, and (4) Neighborhood space of behavior change of the target wanted. Therefore, then the purpose of this study is to analyze the independent aspect of PBL policy implementation in Manado, by using qualitative research phenomenology method. The findings of this study revealed that, the implementer was confronted with the policy's independent aspect that concerned with: (1) Territorial vast, amount and density of population, various educational levels/degrees, revenues, social cultural condition, the increasing of population year by year, technical complexity in conducting communicational socialization because of the diverse abilities: the heads of domain understood the program, district facilitator, (2) The diversity of targeted groups behavior which tagged with the various level of education, ages, skills, genders, physical condition (deformity), social cultural and politics, (3) Percentage of target groups which is 20.427, the amount of unemployment 6.278 , malnourished people are 226 in sum, pre-welfare family are 5010 in sum, the

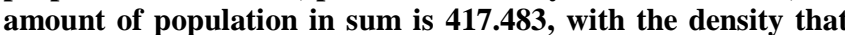
reached 2.686 soul/per-square.., (4) Neighborhood space of behavioral change of the target wanted by a complexly difficult policy to be achieved since the objective of policy is very ideal compare to the realization of funds allocation.
\end{abstract}

Keywords - Independent Aspect, Policy Implementation, Neighborhood Based Establishment, Manado.

\section{INTRODUCTION}

Countemeasure of society's welfare Manado were executed through Envionmental Based Establishment Policy
(PBL) with one of the programs, that is to increase low economic people's revenue.

The implementer of technical policy is Society Empowerment Board and Domain Government (BPMPK) meanwhile the program implementer is (504) Heads of domain. In implementing the policy, there are three (3) main crucial activity that would be better being done which somehow wrote by Mazmanian and Sbatier, by classifying policy's implementation into three characteristics which are: 1) independent aspect, 2) intervening aspect, 3) dependent aspect. Independent aspect concerning with how. Independent aspect emphasized about the necessity of comprehending and analyzing characteristic of the problems out of the policy. Intervening aspect is the aspect between independent and dependent aspect, which ragard with how the implementation process. The dependent aspect regard with the comprehension, obedience, real result and revision of the policy [1].

Policy implementation PBL experienced difficulty in controling independent policy's problems which are: 1) the technical complexity which facing by the implementer, 2) the diverse behavioural targeted groups in 504 range of the domains, 3) percentage of target group was so high compare to the population of Manado, and 4) Neighborhood space of behavioral change of the target. Several policy's implementation problems PBL, are as follow: 1) the conduction of socialization that had not been executed yet as the policy guide, 2) the perception concerned with the policy implementation between technical conductor and program conductor, target groups and society had not a line yet, 3) the ability of Mapalus Society Group is still weak in composing a particular proposal, 4) less comprehension of the facilitator of particular domain regard with his function in succession of Mapalus Society Group's tasks/assignments, 5) misunderstanding of the fund source determining, 6) the low ability of chief of the domain in implementing the policy. Based on the background of the matter, then it is needed to investigate how the policy implementation of Neighborhood based Establishment 
(PBL) in Manado if being analyzed from the independent aspect of the policy.

\section{RESEARCH METHODS}

This research used qualitative design with phenomenology method. Main focus of this research is based on the main question which is: why the implementation of PBL policy that aimed to increase destitute society's welfare less likely affected towards the increasing of the welfare of the destitute society in Manado. Based on that main focus that this research was focusing on independent aspect of policy implementation with the focus description that is meant by independent aspect of PBL policy's implementation is the component of complex technic such as: (1) territorial vast, the amount and populous density, (2) the diversity of target's behaviour, (3) persentage of targeted groups, and (4) Neighborhood space of the behavioural change of the target wanted. Therefore, then the purpose of this study is to analyze independent aspect of PBL policy's implementation in Manado, by using qulitative design, phenomenology method. Meanwhile, the program of Neighborhood Based Establishment is the program of establishing which executed to increase society's welfare at the 504 range of domains, whereas domain is the lowest organization in governmental organization structure in Manado. The data colection techniques are: 1) observation towards the destitute society in 504 domains 2) a semi-structured thoughtful interview, towards: a) public figure, b) chiefs of Domain, c) Facilitators of the Domain, d) chief of village, e) technical implementer who is BPMPK, 3) obtained document form: 1) Manado in Numeral, 2) BPMPK Manado. Data analysis technic were conducted from the beginning to the process of investigation was running with data analysis technic which refered to reference [2] with the procedure, data reduction, data serving, deducing or verifying.

\section{RESULTS AND DISCUSSION}

In implementing public policy then the models of policy implementation that offered theoretically. Reference [3] interpreted implementation of model policy are: (a) Model Van Meter and Van Horn who emphazised that between public policy, implementer and public policy must run a line to reach the aims and target. Meanwhile determinant aspect of policy implementation are: 1) communication interorganizations which engaged in the public policy as well, whereas communication aspect can be a sustaining of policy implementation and barrier of policy implementation, 2) characteristics of policy implementer. Policy implementer suppossed to have disposition and strong commitment as its purpose. Without disposition and strong commitment towards the obejctive of the policy, so that the existance of that implementer will instead become barrier to achieve the objective of policy, 3) economic condition, social, and politic around the policy. That condition is a determinant aspect that it is required an attempt to create a surround atmosphere for society can participate actively in sustaining the success of achieveing the objective of the policy, 4) the tendency of implementer's behaviour. Implementer sometimes shows the unsupported behaviour to the policy or vice versa. Thus, it is needed to ensure that the implementer was really well prepared in in implementing the policy, (b)
Model Mazmanian and Sabatier that classify the process of implementation into three characteristics that are as follow: 1) independent aspect or aspect out of the policy

yet it requires a measurement before implementing the policy in other words identifying the aspects out of the policy which affected the policy implementation 2) intervening aspcet or policy's characteristics, which is the factor between independent and the dependent aspect, the accuracy of fund sourcing alocation, hierarchy interinstitution, regulation, the placement of the offical conductor of social condition, economy, technology endorsement, public support, and 3) external dependent aspect that affecting the policy implementation. Dependent aspect concerning the process of implementation such comprehension, obedience, real result and revision of the policy, (c) Grindle model which emphasizing that the success of implementation intensely determined by the content of the policy. The essence of the policy supossed to compose a certain patern firmly about community necessity which influenced by the implementation, the later usage will be resulting by the existence of the policy and its implementation, how regulator of the policy positioning position, how the readiness of implementer of the policy in implementing it, how is the condition of the target that had been planned by the policy and how was the availability of the fund that endorsing the implementation of the policy, (d) Elmore model that put emphasize on the engagement of the society who becomes the target of policy to be engeged in the formulation and the implemenattion of the policy. Meanwhile implementation of the policy suppossed to be endorsed by government commitment and the avaialability of the implementer to a achieve the objective of the policy and (e) Edward model which recommended that, for the effectiveness of the policy implementation suppossed to observe the four main issues which are: communication, source power, disposition and commitment of the implementer and bureaucrats structure. This model emphasized that the effectiveness of a particular policy depends on four components whereas those components are correlated one another, influencing one another even can be the aspect of barrier nor endorsement of policy implementation. The four components that suppossed to be observe between related party in the policy which are the implementer and society, human resources component and fund resources that availabale for the necessity of policy implementation, component of behaviour attitude that deal with commiitment of the parties that engaged in the implementation of policyto susatin the success of achieving the policy's objective, and the last is components of bureaucrats structure which implementing the policy.

Independent aspect of policy implementation of Neighborhood Based Establishment in Manado adalah:

\section{Technical Complexity.}

Technical implementer of the policy was encountered with the technical comlexity which regard with: 1) territorial vast of Manado which is $157,26 \mathrm{Km} 2,2$ ) population amount 417.483 souls, 3) level of population density reached 2.686 soul/Km2, 4) the increasing of population amount of Manado year by year as the cause of Manado as: a) place for productive age category finding vacancy for the existence of 1.320 private organizations and b) governmental activity center as consequence of Manado as the capital of North Sulawesi province. The rapid growth of population year by 
year affected onto the increasing of destitute society amount which is 20.427 people, the unemployment 6.278 people in sum, malnourished people and currently 226 people in sum, pre-welfare family 5010 in sum [4]. Territorial vast, population amount, density level and the increasing of population is one of the independent aspects that affecting the implementation and the success of policy implementation. Reference [5] sugessting the importance of identifying the matter out of policy since that aspects influencing the implementation and the success of it. The technical complexity of the policy implementation which concerned with the territorial vast, population amount, level of density and the increasing of population is an independent aspect of PBL policy implementation in Manado. The other party that facing technical complexity in conducting socialization towards the implementer of the program which are 504 heads of domain for the wide of territorial scope, the huge amount that must be understood that is all subdistrict heads, village chief, Facilitator, Heads of the domain and public figure. The ability to comprehend the policy which being continued by constructing various chief of domain proposal. This circumstance emerging the difficulty in implementing it. For another party, facilitator of domain whose background is education or skill which dominantly had not sustaining the main task and his function as the facilitator, since facilitator inclined to be raised based on nepotism instead of ability and skills as the facilitator. Therefore, the determination of chief of domain suppossed to pay attention on the aspect of power resource somehow recommended in model of Edward dan Grindle, (Nugroho 2011). Theoretically Mazmanian dan Sabatier dan Elmore, (Nugroho 2011), offered that policy implementation which suppossed to be preceeded by identifying the matter out of of the policy, human resources and how far the implementer of the policy about the objective, strategy, policy activity, since that aspect would determine the success of that policy implementation.

\section{Communication or Socialization}

Socialization is a way to communicate the content of the policy. PBL policy documents determined that socialization regard with the policy conducted along 14 days for all elements of the related chief, technical implementer and program implementer yet the fact is the socialization merely held along 5 days and 2 days for implementer of the program. The conduction of socialization like this definitely will affect on the low comprehension concern with the implementer of the program in implementing the policy. This circumstance was not a line with the document of PBL policy which mentioned that had a less socialization and disemination of information towards the policy would cause on the incomplete comprehension among program implementer and the target, whereas when his/her turn able to fading the real essence and the objective of the policy. With the full comprehensive model of socialization, well planned and integrated and gradually, the same perception of all parties can be achieved as well. This is a line with the perspective of Van Meter and Carl E. Van Horn and Edward (Akib,2012) which recommend communication as the place to socialize the objective, content, target of policy were the determinant aspects which impeded or affecting even may determine the success of the policy. Had held as planned, organized, and complete as the demand of policy's content, that it would then affected towards the success of policy, however had not being conducted as how it suppossed to be, then the communication and socialization will become impeded factor of the implementation and the success of it.

\section{Diversity of Group Target Behaviour}

As for the target of PBL is to increase the welfare of low economic people in the 504 range of domains, possessed a distinctive characteristics. The variety of target's behaviour marked by the following difference: level of education, level of needed, ages, skills, gender, physical appearance (deformity), social cultural and politic. The target group posses various necessity even various behaviour in solving poverty matter. Occasionally, there is target that strongly motivated to be empowered, yet in the other hand there are passive and ignorant people as well. Lifestyle of the policy target are various, the skills, ages, gender, physical condition are different as well. Those are the independent aspect that affecting the implementation and the success of the policy. The result of interview, observation, and documents showed that implementation of the policy still excluded the aspect of diversity of targets in 504 domains. That condition had not being counted as the aspect that determine the failure and the success of policy implementation. Theoretically Van Meter and Carl E. Van Horn, Masmanian and Sabatier which discussed by reference [1] and [3] suggested to pay attention onto aspect that influencing the implementation of the policy which are as follow: social, economy and politic condition. Reference [5] wrote that one of the aspects that influencing the success of implementation is the characteristics of neighborhood. In other words, the diversity of target behaviour seen from that aspect aspect that is independent in the succession of policy implementation.

\section{Percentage of target group}

The target group which is the destitute people are 20.427 in sum, unemployment 6.278 people, malnourished peple currently 226 people, pre-welfare family are 5010, meanwhile the total of population are 417.483 soul, with the level of density that $2.686 \mathrm{jiwa} / \mathrm{Km} 2$ [4]. Those were the group that became target of policy implementation. The data showed that the groups that became target of policy quite high. The amount of destitute society will even keep increasing as the consequence of Manado as trading canter and governmental center. Meanwhile, the fund that submitted by 504 chiefs of domain in the proposal particularly Rp 28.571.894.809 and the fund that being realized were $\mathrm{Rp}$ 4.911.466.239 in sum, (2012). Between the sum of destitute people that has been the target of of policy implementation with the realized fund can be ensured that there have not affected yet towards the success of policy. The data showed that between target group that widely spread at the 504 domain and fund that realized were really inadequate to increase destitute society's welfare. Whereas, theoretically Mazmanian and Sabatiar suggested to consider the amount of target groups with the total of population with the availability of sources, and fund in achieving the success of policy implementation.

\section{Neighborhood Space of Behavioural Change wanted}

Nugroho stated that, occasionally implementer were dealing with the unexpected field matter and occasionally were not met in the concep. Reference [1] reminding that implementer suppossed to consider the events that emerged when the policy were implemented. PBL policy were based on the consciousness comprehending that:1) destitute 
problem shall be able to be finished by people that is in the particular domain, 2) society are obviously the ones that really understood and knew the condition of infrastructural matter, social and economy, 3) thus, it is hoped that society will directly engaged in the attempt of finishing the matter, society became the main actor not the, in the process of managing the neighborhood, 4) people that will be actively engaged in the process of increasing the capacity and the welfare of their own, 5) region government, private party, and other people merely as the facilitator that aid for accelerating and succeding the process of independent. The special objectives of PBL are: 1) the increasing of society's participation in decision making, 2) the increasing government capacity in serving the destitute people, 3) the increasing of social financial based on local potencial, and 4). The increasing of inovation for society's empowerment. For instance, the realization of calculated fund of 2012 event for social and economy were Rp. 1.162.000.000,-, 2013 Fiscal Year Rp. 2.016.000.000,- (documens of realized BPMPK fiscal) compare to the change of the behaviour wanted by PBL policy, then it can be said that the objective of that policy had not been achieved yet whereas theoretically it was suggested that the change of behaviour wanted with fund sources provided suppossed to be caounted.

\section{CONCLUSION}

This research concludes that the independent aspect the of policy implementation of Neighborhood Based Establishment in Manado are as follow: (1). Territorial vast, the amount of population, the density population and the increasing of population in Manado that keep increased year by year. (2). Diversity of behaviour of the target group were marked with the distinctions of: educational level, level of necessity, age, skill, gender, physical condition (deformity), social cultural and politic. (3). Percentage of target group is quite high compare to the sum of the realized fund year by year. (4).Neighborhood space of behavioural change wanted in the policy was really ideal that the implementer found difficult to realize it.
Based on that conclusion, that it is suggested before the implementation of policy, the policy being implemented, the preventive/preceeding action suppossed to be done and analyze independent aspects regard with technical difficulty that concerned with territorial vast, population rate, density of population, and the increasing of Manado's society, The behaviour diversity of target group, group percentage compare to the amount of population and Neighborhood space of behavioural change wanted so that those aspects will not affecting the implementation of the Neighborhood Based Estabishment in Manado.

\section{ACKNOWLEDGMENT}

The writers would like to express the gratitude towards: Society Empowerment Board and Domain Government especially to the Head of the boards, Drs W Tahulending, policy Kasubdit of PBL, Hesky Rungkat, SH dan staffs of policy's technical implementer PBL, Facilitator of Kairagi domain, Wawonasa, Wanea, Chief of domain Karombasan, Lawangirung, Buha, Batukota, , chief village 3 dan 5 Batukota domain, chief village 3 Winangun, chief village 2,3,4 Buha as the implementer program, public figures: Dr. Lexi A Lonto, Dr. Julien Biringan, Joupy Mambu, SH, MH, Drs. T Tumakaka and society member which cannot being mention one by one who have participated in the collecting of the data of this research conduction. Also, to Prof. Haedar Akib, Msi, Dr. Charles Tangkau, Msi who had helped the researcher in conducting data analysis.

\section{REFERENCES}

[1] H. Akib, "Implementasi Kebijakan: Apa, Mengapa dan Bagaimana," J. Ilm. Ilmu Adm. Publik, vol. 1, no. 1, pp. 1-11, 2012.

[2] M. B. Miles and A. M. Huberman, "Qualitative Data Analysis (terjemahan).” Jakarta: UI Press, 2007.

[3] R. Nugroho, Public Policy. Jakarta: Elex Media Komputindo Kelompok Gramedia, 2011.

[4] BPS Kota Manado, Manado dalam angka 2012. Manado: BPS Kota Manado, 2013.

[5] D. A. Mazmanian and P. A. Sabatier, Effective policy implementation. Free Press, 1981. 